\title{
Colon Mucinous Adenocarcinoma
}

National Cancer Institute

\section{Source}

National Cancer Institute. Colon Mucinous Adenocarcinoma. NCI Thesaurus. Code C7966.

An invasive adenocarcinoma of the colon characterized by the presence of pools of extracellular mucin. Malignant glandular epithelial cells are present in the mucin collections. Mucin constitutes more than $50 \%$ of the lesion. 